\title{
Case report of undiagnosed retrosternal goitre - an unpleasant finding during complex cardiac surgery procedure
}

\author{
Igor Medved ${ }^{1}$, Marin Oštrić1 ${ }^{*}$, Salem Osman', Aleksandra Ljubačev ${ }^{1}$, Alfred Božićc \\ From 23rd World Congress of the World Society of Cardio-Thoracic Surgeons \\ Split, Croatia. 12-15 September 2013
}

An 84-years old patient was scheduled for elective, combined procedure of aortic valve replacement and coronary artery bypass grafting. After median sternotomy was done, there was a finding of unusual retrosternal mass. Concurrently, otherwise routine procedure, changed it course. During surgical manipulation, patient started to show signs of thyreotoxic crisis.

Patient was initially stabilised with intravenous metoprolol and amiodarone, blood was taken for analysis and we decided to continue with planned procedure.

Bioprosthesis and vein graft on PD were implanted. During operation, blood analysis came through and revealed high levels of FT4 - free thyroxin : 44,10 pmol/L (with normal values of $11,5-22,7 \mathrm{pmol} / \mathrm{L}$ ).

After CPB termination and adequate hemostasis, with help of general surgeon, partial thyreoidectomy was done.

In early postoperative course, patient recived some inotropic support and was extubated on 4th postoperative day. Except for some minor restlessness, recovery went uneventfull and 84 years old patient was released in good health, on 18th postoperative day.

Upon release, patient was reffered to endocrinologist for further treatment.

\footnotetext{
* Correspondence: mostric@inet.hr

'Department of Cardiac Surgery, Clinical Hospital Center Rijeka, Rijeka,

Croatia

Full list of author information is available at the end of the article
}

\section{Authors' details}

'Department of Cardiac Surgery, Clinical Hospital Center Rijeka, Rijeka, Croatia. ${ }^{2}$ Department of Anesthesiology and Intensive Care, Clinical Hospital Center Rijeka, Rijeka, Croatia.

Published: 11 September 2013

doi:10.1186/1749-8090-8-S1-P31

Cite this article as: Medved et al: Case report of undiagnosed retrosternal goitre - an unpleasant finding during complex cardiac surgery procedure. Journal of Cardiothoracic Surgery 2013 8(Suppl 1):P31.
Submit your next manuscript to BioMed Central and take full advantage of:

- Convenient online submission

- Thorough peer review

- No space constraints or color figure charges

- Immediate publication on acceptance

- Inclusion in PubMed, CAS, Scopus and Google Scholar

- Research which is freely available for redistribution
C Biomed Central 